\title{
Examining the Relationship between Instructional Leadership and Organizational Health
}

\author{
Hanifi Parlar ${ }^{1}$, Ramazan Cansoy ${ }^{2}$ \\ ${ }^{1}$ Istanbul Commerce University, Faculty of Humanities and Social Sciences Department of Educational Sciences, \\ Istanbul, Turkey \\ ${ }^{2}$ Karabük Üniversitesi, Faculty of Letters, Department of Educational Sciences, Karabuk, Turkey \\ Correspondence: Ramazan Cansoy, Karabük Üniversitesi, Faculty of Letters, Department of Educational Sciences, \\ Karabuk, Turkey.
}

Received: February 6, 2017

Accepted: February 16, 2017

Online Published: February 22, 2017

doi:10.11114/jets.v5i4.2195

URL: https://doi.org/10.11114/jets.v5i4.2195

\begin{abstract}
The aim of this study was to examine the relationship between school administrators' instructional leadership behaviours, and organizational health of schools. The participants were 538 teachers working in elementary, middle and high schools located in the Umraniye district of Istanbul. The data was gathered through the "School Principals' Instructional Leadership Behaviours Questionnaire" and the "Organizational Health Inventory". In data analysis, the arithmetic mean, Pearson Product-Moment Correlation Coefficient, and Multilinear Regression Analysis were used. The results showed that the school principals performed the instructional leadership behaviours of determining and sharing the objectives of the school at the highest level. Among the organizational health dimensions of the schools, initiating structure was perceived at the highest level, while resource support and academic emphasis were perceived at lower levels compared to other dimensions. In the study, positive and significant correlations were found between the sub-dimensions of instructional leadership behaviours and those of organizational health of schools. The sub-dimensions of instructional leadership together explained $49 \%$ of the variance in organizational health. On the other hand, only determining and sharing the objectives of the school and forming a regular instructional-learning environment and positive school climate among the instructional leadership behaviours were positive and significant predictors of organizational health of schools.
\end{abstract}

Keywords: instructional leadership, organizational health, healthy schools

\section{Introduction}

Organizational health is among significant research topics associated with different personal and organizational variables in schools (e.g. Güçlü, Recepoğlu \& K1lınç, 2014; Korkmaz, 2005; Recepoğlu \& Özdemir, 2013; Roney, Coleman \& Schlichting, 2007). While maintaining the existence of the organization, organizational health makes reference to environmental harmony and continuity. Depending on the organizational health of schools, student learning and achievement increase, and schools become more effective (Cemaloğlu, 2007; Güçlü, Recepoğlu \& Kılınç, 2014; Hoy, Tarter \& Bliss, 1990; Korkmaz, 2005; Roney, Coleman \& Schlichting, 2007; Vassie \& Lucas, 2001). In the literature, there are studies that examined the relationships between organizational health, and student achievement (Korkmaz, 2005; Roney, Coleman \& Schlichting, 2007), teacher commitment (Tsui \& Cheng, 1999), school climate and effectiveness (Hoy, Tarter \& Bliss, 1990), leadership styles (Cemaloğlu, 2007; Korkmaz, 2007), job motivation (Güçlü, Recepoğlu \& Kılınç, 2014) and school effectiveness (Türker, 2010). These studies aimed to explain the organizational health of schools. However, it was thought to be useful also to examine its relationships with different organizational and personal dimensions in order to better understand organizational health in schools and make inferences towards practice.

The continuity of organizational health depends on the realisation of certain elements in schools. These are setting achievable goals, ensuring communication adequacy, informing stakeholders of developments within the institution, power equalisation, individuals' commitment to the institution, a peaceful environment, being open to innovations, and effective problem solving (Miles, 1965). In a healthy school, there is a harmony at the technical, administrative and institutional levels. Problems regarding instruction and learning are solved, activities are done to enhance commitment, 
confidence and motivation, and requests from the school's environment are evaluated in an autonomous and unique way. Consequently, schools concentrate on student achievement and learning, which are their actual tasks (Hoy, Tarter \& Kottkamp, 1991). When organizational health is regarded as an outcome, school principals' instructional leadership behaviours can be expected to have an influence on the organizational health of schools. This is because instructional leadership refers to the behaviours that school principals need to perform to enhance student learning and instruction (Şişman, 2011). Forming quality instructional environments are related to principals' model behaviours (Williams, 2009). School principals ensure the development of the school staff (Güçlü, 2000). At the same time, they review the processes at school to increase the quality with regard to teaching, and support and evaluate instruction. Besides, they take care of supervision and planning (Sergiovanni, 1984). School principals also support behaviours that encourage teaching and learning (Cranston, 2002). In addition, the administration of educational processes is among the duties of school principals (Okutan \& Kahveci, 2012; Şahin, 2000). In various countries, competencies that reveal instructional leadership behaviours were determined in the context of administrative qualifications. For example, according to the Interstate School Leaders Licensure Consortium (ISLLC) (Turan \&Şişman, 2000), school administrators should exhibit a vision that focuses on enhancing student achievement. In the United Kingdom, the Office for Standards in Education (OFSTED, 1997) specifies improving learning and teaching, and making the teaching staff more professional among the qualifications of school principals. Besides, it is stated that effective school leaders should set academic standards, develop curricula, and create a positive school climate (Bergeson, Heuschel, Alice \& Merle, 2001). There is proof that school administrators are influential in improving schools (Şişman, 2011; Dağ, 2009). It can be argued that the idea behind school principals' being qualified is the goal to change the quality of education in the positive direction. Therefore, it can be inferred that depending on school principals' instructional leadership behaviours, quality instructional environments can be created, schools can regulate themselves in a way to have a better adaptation to their environments, and they can increase their levels of organizational health. Accordingly, it can be stated that there is a positive relationship between school principals' instructional leadership behaviours and the organizational health of schools. In this regard, this study aimed to examine the relationship between school principals' instructional leadership behaviours, and the organizational health of schools.

The results of this study can provide policy makers and practitioners with some meaningful insights towards making schools more effective. At the same time, significant inferences can be made regarding which instructional leadership behaviours are effective in enhancing organizational health, and the instructional leadership dimensions that improve organizational health. However, it can be stated that studies examining instructional leadership and the organizational health of schools have been limited in the Turkish context (Buluç, 2015; Recepoğlu \& Özdemir, 2013). Therefore, this study can contribute to the development of the literature in which organizational and personal variables are discussed.

\subsection{Organizational Health}

Valuing individuals and their having high supervisory beliefs in the tasks they undertake make them feel important. In cases where such a setting cannot be formed sufficiently, student achievement goes down, and reckless behaviours are observed in teachers (Childers \& Fairman, 1986). Malpractices in organizations, inadequate designs in different areas, a poor culture and employees' incompetence lead to unhealthy schools (Dive, 2004). Being a healthy organization is of great importance for schools. This is because a healthy school operate more effectively, and people are satisfied with the school. At the same time, as the organization grows, there is a harmony with the environment. A vision which everybody is happy with is realized (Leovey, Nadkarni, Erdaelyi, 2003). Healthy organizations show continuity by adapting to environmental conditions, and staff members maintain their development (Miles, 1965). In this process of development, individuals carry on learning and staying up-to-date (Dive, 2004). Practices towards improving individuals' skills, participation in decisions made to develop the organization, and strengthening the educational staff help forming healthy schools (Vassie \& Lucas, 2001). Consequently, it can be stated that a good planning, constant development of teachers in the professional sense, more humane attitudes in relationships, and quick adaptation to change are what make schools healthy organizations.

In the context of this study, organizational health was considered in seven sub-dimensions (mis al., 1991; Hoy \& Feldman, 1987). These are institutional integrity, initiating structure, consideration, principal influence, resource support, morale, and academic emphasis. (i) Institutional integrity refers to the school curriculum being maintained as a whole by being adopted by the staff, interaction with different groups outside the school, and protecting teachers against unreasonable requests from outside the school. (ii) In principal effect, school principals influence their own superiors, prevent the hierarchical structure from blocking the activities to be implemented, and become effective models in the development of the school. (iii) Consideration points out the personal characteristics of the school principal such as sincerity, friendship and openness. (iv) Initiating structure emphasises school principals' managerial skills, behaviours towards duty and success, and working in a collaborative way. It also refers to the behaviours that are supportive and towards success. Previous performances are aimed to be matched by the school staff. (v) Morale is about a positive 
working climate, individuals' loving their job, and an environment that is based on collaboration. (vi) Resource support refers to providing the physical conditions for the school, and accessing materials when needed. (vi) Academic achievement indicates students' beliefs that they can be well-educated and be successful, and an understanding based on student achievement.

\subsection{Instructional Leadership}

Since instructional leadership has started to be seen as an important variable in effective schools, various studies have been conducted on this issue (Şişman, 2011). School principals' instructional leadership behaviours consist of characteristics such as supervision and evaluation, coordinating curriculum, and monitoring student development (Hallinger \& Murphy, 1985). On the other hand, in studies on instructional leadership, this issue is examined as the characteristics and duties of instructional leaders, and instructional leadership models (Harchar \& Hyle 1996 cited in Şişman, 2011).

Instructional leadership is the pattern of behaviours that school principals personally exhibit, or make the staff to perform, in order to ensure student learning (De Bevoise, 1984). "Instructional leadership refers to the power and behaviours that school principals, teachers and supervisors use to influence individuals and situations related to the school. The most important aspect of instructional leadership that distinguishes it from the leadership conceptualisation is that the focus is on the learning and teaching processes at school" (Şişman, 2011, p.54). School principals have certain qualifications as instructional leaders. These are knowing about new learning and teacher strategies, explaining effective instructional strategies for different age groups, developing the staff and guiding them on instructional strategies, assessing curricula by considering student learning outcomes, making evaluations regarding whether objectives are achieved or not, informing the staff about these evaluations, understanding the importance of student learning, monitoring the achievement of objectives, and guiding students (Smith \& Andrews, 1989).

The instructional leadership behaviours of school behaviours that were examined in the context of this study are as follows: Determining and sharing the objectives of the school, administering the curriculum and the instructional process, assessing the instructional process and students, supporting and improving teachers, and forming a regular instructional-learning environment and positive school climate (Şişman, 2011). These dimensions and characteristics are as in the following; (i) determining and sharing the objectives of the school refers to the school principal's behaviours of defining the objectives of the school, sharing these objectives with the stakeholders, emphasising them, and playing the pioneer role in achieving them.(ii) administering the curriculum and the instructional process refers to the principal's behaviours of providing the conditions and opportunities towards achieving the objectives of the curriculum, and regulating the curriculum.(iii) assessing the instructional behaviours and students indicates being able to supervise, monitor and evaluate student achievement, discuss problems with the school staff when necessary, reveal the level of achieving the objectives, and revising the new objectives when necessary. (iv) supporting and improving teachers refer to enhancing professional competence, providing opportunities for this competence to be used in schools, rewarding teachers based on success, and announcing achievements. (v) forming a regular instructional-learning environment, and positive school climate pertains to creating environments that value learning and instruction, pioneering and supporting new ideas in education, recognising different sub-cultures within the school, and providing a positive orientation related to education and instruction.

Revealing the relationship between school principals' instructional leadership behaviours and the organizational health of schools can help to enhance the quality of education in schools. It is hypothesised by the researchers that as instructional leadership behaviours improve, the instructional health of schools can improve. In this regard, it can be stated that examining the consequences of school principals' instructional leadership behaviours is of significance in terms of improving the organizational health of schools Inferences can be made in this way regarding improving the organizational health of schools, and instructional leadership behaviours. The following research questions were addressed in this context:

1-What are the levels of school principals' instructional leadership behaviours and the organizational health of schools based on teachers' perceptions?

2-Is there a significant relationship between the school principals' instructional leadership behaviours and the organizational health of schools based on teachers' perceptions?

3-Do the school principals' instructional leadership behaviours significantly predict the organizational health of schools based on teachers' perceptions? 


\section{Method}

\subsection{Research Design}

The independent variables of this study which was conducted in the relational model were school principals' instructional leadership behaviours (determining and sharing the objectives of the school, administering the curriculum and the instructional process, assessing the instructional process and students, supporting and improving teachers, and forming a regular instructional-learning environment and positive school climate), and the dependent variables were the sub-dimensions of the organizational health of schools (institutional integrity, principal influence, consideration, initiating structure, resource support, morale, and academic emphasis).

\subsection{Population and Sample}

The population of the study comprised of all teachers working in the Umraniye district of Istanbul during the 2016-2017 school year. On the other hand, the sample consisted of 538 teachers selected from this population through random sampling. Among these participants, 354 were female (66\%), and 184 were male (34\%). Teachers at elementary, middle and high school located in the Umraniye district participated in the study. The average age of the participants was 36 . The teachers' length of service in their schools was an average of 4.66 years in average.

\subsection{Data Gathering Tools}

\subsubsection{School Principals' Instructional Leadership Behaviours Questionnaire}

This questionnaire was developed by Şişman (2011) to reveal school principals' levels of performing instructional leadership behaviours. It consists of 50 items. These items are rated on a 5-point Likert scale from "(1) Never" to "(5) Always", and constitute five dimensions. These dimensions are (i) determining and sharing the objectives of the school (DS), (ii) administering the curriculum and the instructional process (AC), (iii) assessing the instructional process and students (AI), (iv) supporting and improving teachers (SI), and (v) forming a regular instructional-learning environment and positive school climate (FR). Sample items include "The school principal ensures that classes start and end in time", "The school principal rewards teachers due to their special efforts", and "The school principal ensures that families and the environment support the school to enhance student achievement." The Cronbach's Alpha value was calculated as .92 for the reliability of the instructional leadership scale (Şişman, 2011).

Whether the 50 items and five factors in the instructional leadership scale fitted the data in this study was also examined. Confirmatory factor analysis (CFA) was performed for this purpose. Because the factor loading values were low and decreased the reliability of the whole scale, two items from the dimension "administering the curriculum and the instructional process", and one item from the dimension "assessing the instructional process and students" were excluded from the scale. According to the fit indexes calculated after the exclusion of these items in CFA, it was found that the model showed an acceptable fit with the data, $(\chi 2=2573.90 ; p<.05 ; \mathrm{df}=1013 ; \chi 2 / \mathrm{df}=2.54$; RMSEA $=.053$; $\mathrm{CFI}=.94 ; \mathrm{GFI}=.82 ; \mathrm{AGFI}=.80$ ). The factor loadings of the scale items ranged between .66 and .89 . The Cronbach's Alpha coefficients calculated in this study were .96 for "determining and sharing the objectives of the school", .91 for "administering the curriculum and the instructional process", .96 for "assessing the instructional process and students", .95 for "supporting and improving teachers", .97 for "forming a regular instructional-learning environment and positive school climate", and .98 for the whole scale. As a result, it was concluded that the five-factor structure was valid for the present study.

\subsection{Organizational Health Inventory}

This inventory was developed by Hoy and Miskel (1991) to measure organizational health, and adapted to Turkish by Cemaloğlu (2006, 2007). The original inventory contained 44 items and seven dimensions. In the adaptation by Cemaloğlu, it included 39 items and seven dimensions. It was rated on a 4-point Likert scale with options ranging from "(1) Rarely occurs" to "(4) Very frequently occurs". The total variance explained was $62 \%$, and there were a total of seven dimensions in the inventory. These dimensions were (i) institutional integrity (II), (ii) principal influence (PE), (iii) consideration (CO), (iv) initiating structure (IS), (v) resource support(RS), (vi) morale (MO), and (vii) academic emphasis (AE). The Cronbach's Alpha values calculated for the reliability for the sub-dimensions of the inventory ranged between .60 and .92 . The Cronbach's Alpha value for the whole inventory was .93 . Higher scores in the sub-dimensions of the inventory show a higher level of organizational health. Sample items include the following: "The morale of the teachers in our school is high", and "The school principal is willing to make changes in our school.".

Whether the 39 items and seven dimensions in the institutional health inventory fitted the data in this study was also examined. According to the fit indexes calculated in CFA, it was found that the model showed an acceptable fit with the data, $(\chi 2=1593.90 ; p<.05 ; \mathrm{df}=712 ; . \chi 2 / \mathrm{df}=2.24 ; \mathrm{RMSEA}=.048 ; \mathrm{CFI}=90 ; \mathrm{GFI}=.87$; AGFI $=.85)$. The factor loadings of the items in the inventory ranged between .42 and .83 . The Cronbach's Alpha coefficients calculated in this 
study were .69 for institutional integrity, .66 for principal influence, .82 for consideration, .82 for initiating structure, .86 for resource support, .83 for morale, .77 for academic emphasis, and .92 for the whole inventory.

\subsection{Data Analysis}

SPSS 17 was used for data analysis. Whether there were multiple changes, missing data and outliers were also examined. The arithmetic means of the principals' instructional leadership behaviours and the organizational health of schools were calculated. In order to reveal the relationships between the variables, Pearson Product-Moment Correlation Coefficient and Multiple-Linear Regression Analysis were employed.

Assumptions regarding regression analysis were tested in the study. The tolerance value being lower than .20, the VIF value being higher than 10 , CI value being higher than 30, and the correlations between independent variables being .90 and above show that there is multicollinearity at a serious level. In such a case, there could be problems in the regression analysis (Büyüköztürk, 2010). In this study, the relationship between the predictive variables ranged between $r=.82$ and $r=.86$. The tolerance values were close to .20 and ranged between .13 and .19 , the VIF values were lower than .10 and ranged between 5.2 and 7.4, and the CI values were between 10 and 30 . When the CI, VIF, tolerance and $\mathrm{D}-\mathrm{W}(2.05)$ values were evaluated together, it was assumed that there was no multicollinearity problem. The skewness and kurtosis values of the data ranged between -1 and +1 . The data was assumed to have a normal distribution based on mode, median and arithmetic mean values, normal Q-Q graph, and skewness and kurtosis values. The skewness and kurtosis values being between -1 and +1 shows normal distribution (Şencan, 2005).

With regard to the fit indices used while conducting confirmatory factor analysis, GFI is accepted as good fit if the coefficient obtained from AGFI is .85 (Anderson \& Gerbing, 1984 \& Cole, 1987) or .90 (Kline, 2005; Schumacker \& Lomax, 1996). Values obtained from RMSEA that are .10 and below are regarded as sufficient for fitness. The ratio of $\chi 2 / \mathrm{df}$ being between 2 and 5 refers to good fit, whereas it being lower than 2 refers to perfect fit (Jöreskog \& Sörbom, 2001).

\section{Findings}

\subsection{Relationships between Variables}

Table 1 presents the arithmetic means and standard deviations related to the dependent and independent variables, and the coefficients of the relationships between these variables.

Table 1. The relationship between the organizational health of schools and instructional leadership behaviours

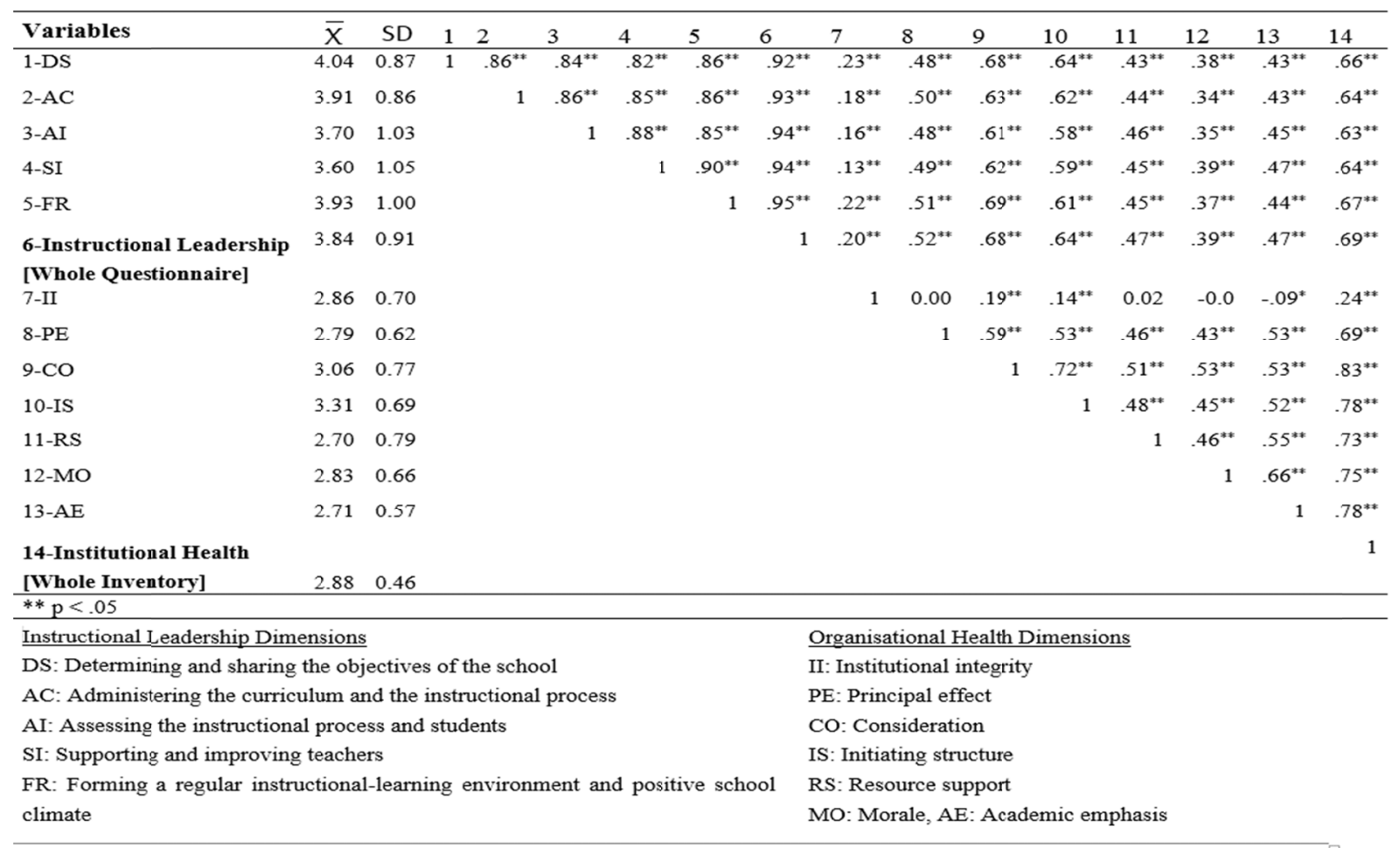


As is seen in Table 1, the teachers' perceptions of the school principals' levels of performing instructional leadership behaviours were at the highest level in the dimension of determining and sharing the objectives of the school $(\bar{X}=4.04)$, and at the lowest level in the dimension of supporting and improving teachers $(\bar{X}=3.60)$. The teachers' perceptions of the organizational health of schools were at the highest level in the dimension of initiating structure $(\bar{X}=3.31)$, and at the lowest level in the dimension of resource support $(\bar{X}=2.70)$.

When the correlation coefficients between the variables are examined according to the data presented in Table 1, the school principals' instructional leadership behaviours based on the teachers' perceptions were positively and significantly related to the organizational health of schools, $(r=.69, p<.05)$.Considering the relationships between the sub-dimensions, the strongest and significant relationships regarding the sub-dimensions of school principals' instructional leadership behaviours and the organizational health of schools were between forming a regular instructional-learning environment and positive school climate, and consideration $(r=.69, p<.05)$, and determining and sharing the objectives of the school, and consideration $(r=.68, p<.05)$, whereas the weakest and significant relationship was between supporting and improving teachers, and institutional integrity $(r=.13, p<.05)$.

\subsection{Predicting the Institutional Health of Schools}

The results of the multiple linear regression analysis regarding the prediction of the levels of the institutional health of schools by the school principals' instructional leadership behaviours are presented in Table 2.

Table 2. Multiple regression analysis for the relationship between the organizational health of schools and instructional leadership behaviours

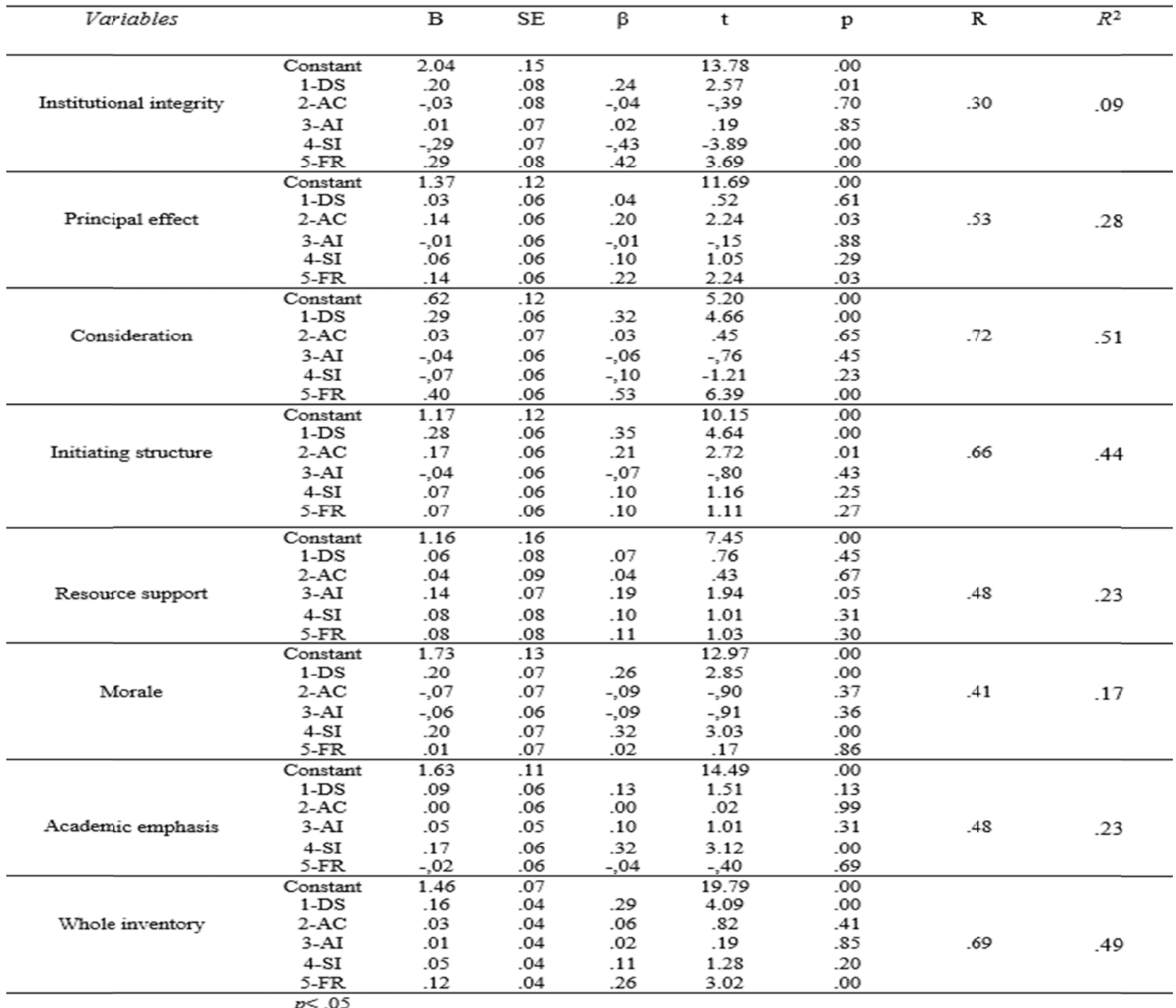

According to the results of the regression analysis, the schools principals' instructional leadership behaviours together were significantly related to consideration $(R=.72, p<.05)$, initiating structure $(R=.66, p<.05)$, resource support $(R=.48$, $p<.05)$, academic emphasis $(R=.48, p<.05)$, principal effect $(R=.53, p<.05)$, morale $(R=.41, p<.05)$, and institutional 
integrity $(R=.30, p<.05)$ which are the dimensions of the institutional health of schools. The highest variance explained by all sub-dimensions of the principals' instructional leadership behaviours together was the dimensions of consideration with $51 \%$ and initiating structure with $44 \%$. These were respectively followed by principal effect with $28 \%$, resource support with $23 \%$, academic emphasis with $23 \%$, and morale with $17 \%$.

The school principals' instructional leadership behaviours based on the teachers' perceptions together were positively and significantly related to the organizational health level of schools $(R=.69, \mathrm{p}<.05)$. The predictor variables belonging to instructional leadership behaviours explained $49 \%$ of the variance in the organizational health level of schools. Determining and sharing the objectives of the school $(\beta=.29, \mathrm{p}<.05)$ and forming a regular instructional-learning environment and positive school climate $(\beta=.26, \mathrm{p}<.05)$ were significant predictors of organizational health. However, administering the curriculum and the instructional process $(\beta=.06 \mathrm{p}>.05)$, assessing the instructional process and students $(\beta=.02, \mathrm{p}>.05)$, and supporting and improving teachers $(\beta=.11, \mathrm{p}>.05)$ were not significant predictors of the organizational health of schools.

\section{Discussion and Conclusion}

The study revealed that instructional leadership behaviours and the organizational health of schools were positively and significantly related. Moreover, instructional leadership behaviours were found to be an important variable predicting the institutional health of schools.

The study revealed that based on the teachers' perceptions, the school principles exhibited the behaviours of determining and sharing the objectives of the school at the highest level, while performing the behaviours of supporting and improving teachers at the lowest level. There are findings reported in the literature that overlap with those revealed in this study (Buluç, 2015; Sarıkaya \& Erdoğan, 2016; Serin \& Buluç, 2012; Şişman, 2011). The fact that the school principals' behaviours towards determining and sharing the objectives of the school were perceived at a high level can be seen as a positive result. Based on these findings, it can be stated that school principals make explanations about the important objectives of schools, and sufficiently inform teachers. In this regard, Serin and Buluç (2012) asserted that the bureaucratic structure and following the national education legislation can be influential in schools. In a study, Çelikten (2004) observed a school principal, and reported that the tasks that he spent most of his time with were overall administration, planning and walking around, respectively. It is stated that school principals allocate a considerable amount of time to meeting teachers in the tasks of administration and walking around. In other words, it can be said that school principals share the objectives of schools with the staff in different ways. However, a noteworthy finding is that the dimension of supporting and improving teachers is being perceived at a lower level than other dimensions. is a finding that should be pointed out. This is because the effectiveness of schools shows a consistency with staff's developing themselves (Rolff, 2008). Therefore, this result can reduce the effectiveness of schools. The behaviours in this dimension not being performed sufficiently can be due to a number of reasons. In their study, Demirtaş and Özer (2014) stated that school principals dealt with the physical conditions of the school and problems other than about instruction in most of their time, and thus could not do instructional leadership. In another study, Özgan and Aslan (2008) stated that the school principals' interaction with teachers was mostly in the form of ordering, and disrupting communication. Accordingly, it can be indicated that teachers are prejudiced against school principals because principals do not spare time to activities towards supporting teachers, or due to other communication problems.

The study revealed that the organizational health of schools were at the highest level in the dimension of initiating structure. This finding is similar to other findings reported in the literature (Güçlü, Recepoğlu \& Kılınç, 2014). This finding can be regarded as positive in terms of showing the initiating structure at a sufficient level. It can be said that school principals possess managerial skills, and exhibit behaviours that are supportive and aimed towards success by adopting collaboration. The organizational health of schools were found to be at the lowest level in resource support and academic emphasis. Resource support and academic emphasis being perceived at a lower level compared to other dimensions can be evaluated as a negative result. The perception of resource support being low shows that physical conditions of schools are inadequate, and there are difficulties experienced with regard to accessing materials when needed. Different studies reported that school principals make a great deal of effort obtaining school equipment, security, providing resources and physical conditions (Çelikten, 2004; Turan, Yıldırım \& Aydoğdu, 2012). Low academic emphasis shows that teachers' expectations of student achievement are not at a sufficient level. Low expectation of achievement may have negative consequences in terms of school outcomes. This is because students struggle more depending on a level of expectation (Chang, 2011). On the other hand, if teachers have a high expectation, they plan their activities accordingly, and focus on the states and behaviours that they can change in students (Hopkins, 2003). Therefore, it can be stated that academic emphasis and resource support should be given more attention for a healthy school environment. 
In the study, positive and significant correlations were found between the sub-dimensions of instructional leadership behaviours and those of organizational health of schools. There are similar findings reported in the literature (Buluç. 2015; Recepoğlu \& Özdemir, 2013). In other words, as school principals' instructional leadership behaviours improve, the organizational health levels of schools also improve. The strongest relationships were found between all sub-dimensions of instructional leadership, and the dimensions of consideration, initiating structure and principal effect, whereas the weakest relationships were found between instructional leadership and institutional integrity. The results of the regression analysis also showed that the dimensions that were explained by instructional leadership behaviours with the highest percentages were consideration, and initiating structure. While consideration emphasises school principals' personal characteristics, it features friendliness, sincerity and being supportive. Initiating structure refers to the managerial success of school principals, and the behaviours performed towards the duty and having success (Hoy \& Feldman, 1987; Hoy et al., 1991). Effective school leaders perform leadership behaviours frequently (Shannon \& Blysma, 2007), encourage collaboration and create a secure school climate (Bergeson, Heuschel, Alice \& Merle, 2001), and are open to communication (Adelman \& Taylor, 2007). Activities that enhance confidence and motivation are done in a healthy school (Hoy et al., 1991). This is because teachers' feeling themselves valuable positively affects student achievement. Studies that reveal the relationship of instructional leadership with organizational and personal characteristics also confirm this situation. For instance, a meta-analysis related to instructional leadership showed significant relationships between instructional leadership, and transformative leadership, affective intelligence, job satisfaction, decision-making skills, school environment, organizational commitment and organizational citizenship (Şişman, 2016). When the positive and significant relationships between instructional leadership behaviours and the organizational health of schools are evaluated as a whole, it can be stated that as school principals' instructional leadership behaviours improve, their human relationships get strengthened, an environment based on mutual respect and confidence is formed, there is more collaboration among school staff, and any sacrifice for student achievement is done as a team. In schools that have these common values, it can be inferred that organizational health is improved.

In the study, it was found that the instructional leadership dimensions positively and significantly explained the sub-dimensions of organizational health. Instructional leadership behaviours were found to explain $49 \%$ of the organizational health in schools. In other words, as school principals' instructional leadership behaviours together explain the organizational health of schools. These findings are similar to those reported in the literature (Buluç. 2015; Recepoğlu \& Özdemir, 2013). On the other hand, the positive and significant predictors of the organizational health of schools were only two sub-dimensions of instructional leadership behaviours, which were determining and sharing the objectives of the school and forming a regular instructional-learning environment and positive school climate. The objectives that are set by the school also enable it to assess itself. The instructional and educational objectives of schools that are effective in terms of instruction are known by the school community (Şişman, 2011). When the objectives of schools are defined, the foundations of school curricula are laid with these objectives, sharing resources as well as their effective and appropriate use are ensured, and the school staff is guided (Hallinger \& Murphy, 1986). Therefore, setting the objectives of the school clearly and sharing them with teachers, students and parents can strentghen the effort to achieve the expectations of the school related to its vision and mission. Besides, the school principals' adoption of these objectives and efforts towards achieving them can encourage the school community. On the other hand, the finding that forming a regular instructional-learning environment and positive school climate was a significant predictor of organizational health can be seen as important. In their study, Ayık and Şayir (2014) reported that the instructional leadership dimension of forming a regular teaching and learning environment positively explained school climate. A quality curriculum and qualified teaching staff along with suitable and sufficient materials can enhance the effectiveness of instruction. However, the two elements that can combine all these are teaching-learning climate and instructional leadership (Krug, 1992). In a healthy school environment, teachers try to improve student achievement and the teaching-learning environment (Hoy et al., 1991). What makes schools effective seems to be common values, and positive and collaborative relationships among individuals (Şişman, 2011). It can be argued that when school principals create environment that ensure teachers and students work willingly, and value new ideas and bring together different orientations for the success of the institution, schools operate more effectively, satisfaction with the school increases, and organizational growth occurs in harmony with the environment. In this respect, the organizational health of schools enhance with the instructional leadership behaviours of determining and sharing the objectives of the school and forming a regular instructional-learning environment and positive school climate.

\section{Recommendations}

Based on the teachers' perceptions, the school principles exhibited the behaviours of determining and sharing the objectives of the school at the highest level, while performing the behaviours of supporting and improving teachers at the lowest level. In this sense, in-service trainings can be organised to strengthen school principals' behaviours of determining and sharing the objectives of the school that are at a low level. 
Based on the teachers' perceptions, the organizational health of schools were at the highest level in the dimension of initiating structure. It was found to be at the lowest level in resource support and academic emphasis. In this regard, the kind of resources schools need can be identified and their needs can be met in this way. The reasons behind the low level of academic emphasis in schools should be investigated, and practices should be implemented to improve it. In addition, monthly meetings can be held in schools to figure out what to do to upgrade the academic level, and the decisions made can be planned and implemented to improve the school.

This study reveals that as school principals perform better instructional leadership behaviours, the institutional health levels of their schools increases. The strongest relationships were found between all sub-dimensions of instructional leadership, and the dimensions of consideration, initiating structure and principal effect. Therefore, the focus can be on enhancing consideration, initiating structure and principal effect in activities aimed at improving schools that do not have an adequate level of institutional health.

The positive and significant predictors of the organizational health of schools were found to be the instructional leadership sub-dimensions of determining and sharing the objectives of the school and forming a regular instructional-learning environment and positive school climate. For this reason, it can be stated that practitioners should pay attention to the behaviours of determining and sharing the objectives of the school and forming a regular instructional-learning environment and positive school climate in order to improve the organizational health levels of schools. Besides, instructional leadership can be made an agenda item in the in-service trainings for school principals organised by the Ministry of National Education, good examples can be presented to them so that they can gain instructional leadership behaviours, and they can be encouraged to have a graduate degree.

This study can be supported particularly with qualitative and mixed-method studies. Besides, further studies can focus on the relationship between instructional leadership and organizational health in the context of cause and effect.

\section{References}

Adelman, H., \& Taylor, L. (2007). Safe schools in the context of school improvement. In National Conference on SafeSchools (pp.9-15). Accessed from http://smhp.psych.ucla.edu/publications/safe $\% 20$ schools $\% 20$ in $\% 20$ the $\% 20$ context $\% 20$ of $\% 20$ school $\% 20$ improvem ent.pdf on 26.1.2017

Anderson, J. C., \& Gerbing, D. (1984). The effect of sampling error on convergence, improper solutions, and goodness-of-fit indices for maximum likelihood confirmatory factor analysis. Psychometrika, 49, 155. https://doi.org/10.1007/BF02294170

Ayık, A., \& Şayir, G. (2014). The relationship between school principals instructional leadership behaviours and organizational climate. Electronic Journal of Social Sciences, 13(49), 253-279.

Bergeson, T. Heuschel, Alice, M. \& Merle, D. (2001). Middle level strategies for school improvement. A report from the washington state middle level task force. office of superintendent of public instruction. Accessed from http://k12.wa.us/research/pubdocs/MiddleSchpdffiles/MSpgCover-6.pdf on 26.1.2017

Buluç, B. (2015). Relationship between Instructional Leadership and Organizational Health in Primary Schools. Anthropologist, 19(1), 175-183.

Çelikten, M. (2004). Bir okul müdürünün günlüğ̈̈. Fırat Üniversitesi Sosyal Bilimler Dergisi, 14(1), 123-135.

Cemaloğlu, N. (2006). Examining elementary school teachers' perceptions of organizational health in terms of different variables. Hacettepe University Journal of Education Faculty, 30, 63-72.

Cemaloğlu, N. (2007). The effect of school administrators' leadership styles on organizational health. Turkish Journal of Social Research, 11(2), 165-194.

Chang, J. (2011). A case study of the "Pygmalion Effect": Teacher expectations and student achievement. International Education Studies, 4(1), 198-201. https://doi.org/10.5539/ies.v4n1p198

Childers, J. H., \& Fairman, M. (1986). The school counselor as facilitator of organizational health. The school counselor, 33(5), 332-337.

Cole, D. A. (1987). Utility of confirmatory factor analysis in test validation research. Journal of Consulting and Clinical Psychology, 55, 1019-1031. https://doi.org/10.1037/0022-006X.55.4.584

Cranston, N. C. (2002). School-based management, leaders and leadership: Change and challenges for principals. International Studies in Educational Administration, 30(1), 2-12.

Dağ, Ş. (2009). Determining the school development needs of the state elementary schools in Istanbul. Unpublished Master's thesis. Yıldız Teknik University, İstanbul. 
De Bevoise, W. (1984). Synthesis of research on the principal as instructional leader. Educational Leadership, 41(5), 14-20. Accessed from http://ascd.com/ASCD/pdf/journals/ed_lead/el_198402_bevoise.pdf on 26.1.2017

Demirtaş, H., \& Özer, N. (2014). School administration from the perspective of school principals. Kastamonu Journal of Education], 22(1), 1-24.

Dive, B. (2004). The healthy organization: A revolutionary approach to people \& management (2th Ed.). United States: Kogan Page.

Güçlü, N. (2000). School-based administration. Journal of National Education, (148), 117-126.

Güçlü, N., Recepoğlu, E., \& Kılınç, A. Ç. (2014). The relationship between the organizational health of elementary schools and teachers' job motivation. Acettepe University Journal of Education Faculty, 29(1), 140-156.

Hallinger, P., \& Murphy, J. (1985). Assessing the instructional management behavior of principals. The Elementary School Journal, 86(2), 217-247. https://doi.org/10.1086/461445

Hallinger, P., \& Murphy, J. F. (1986). The social context of effective schools. American Journal of Education, 94(3), 328-355. https://doi.org/10.1086/443853

Hopkins, D. (2003). School Improvement for Real. London: Routledge Falmer.

Hoy, W. K., \& Feldman, J. A. (1987). Organizational health: The concept and its measure. Journal of Research and Development in Education, 20(4), 30-38.

Hoy, W. K., \& Miskel, C. G. (1991). Educational administration: Theory, research, and practice. New York: McGraw-Hill.

Hoy, W. K., Tarter, C. J., \& Bliss, J. R. (1990). Organizational climate, school health, and effectiveness: A comparative analysis. Educational Administration Quarterly, 26(3), 260-279. https://doi.org/10.1177/0013161X90026003004

Hoy, W. K., Tarter, C. J., \& Kottkamp, R. B. (1991). Open schools/healthy schools: Measuring organizational climate. Newbury Park, CA: Sage. Accessed from http://www.waynekhoy.com/pdfs/open_schools_healthy_schools_book.pdf on 26.1.2017

Jöreskog, K., \& Sörbom, D. (2001). LISREL 8.51. Mooresvile: Scientific Software.

Kline, R. B. (2005). Principle and practice of structural equation modeling. New York, NY: Guilford.

Korkmaz, M. (2005). The relationship between organizational health and student achievement in elementary schools. Educational Administration in Theory and Practice, 11(44), 529-548.

Korkmaz, M. (2007). The effect of leadership styles on organizational health. Educational Administration in Theory and Practice, 3(49), 57-91.

Krug, S. E. (1992). Instructional Leadership, School Instructional Climate, and Student Learning Outcomes. Project Report. Accessed from http://files.eric.ed.gov/fulltext/ED359668.pdf on 26.1.2017

Leovey, I., Nadkarni, M. S., \& Erdaelyi, E. (2003). The Joyful Organization: Understanding Organizational Health, Diseases and Joy. New Delhi: Response Books.

Miles, M. B. (1965). Planned change and organizational health: figure and ground. In R. O. Carlson, A. Gallaher, M. B. Miles, R. J. Pellegrin and E. M. Rogers (Eds.), Change Processes in the Public Schools (pp. 11-34) (ED014123). Accessed from http://files.eric.ed.gov/fulltext/ED014123.pdf on 26.1.2016

Office for Standards in Education-Eğitim Standartları Bürosu (OFSTED). (1997). Accessed from http://otmg.meb.gov.tr/belgeler/okul\%20müdürleri\%20standartları.doc on 11.12.2016.

Okutan, M. \& Kahveci, A. (2012). Examining elementary school principals' overall self-efficacy beliefs in terms of various variables (Case of Rize). Kastamonu Journal of Education, 20(1), 27-42.

Özgan, H., \& Aslan, N. (2008). Examining the effect of elementary school principals' oral communication on teachers' motivation. Gaziantep University Journal of Social Sciences, 7(1), 190-206.

Recepoğlu, E., \& Özdemir, S. (2013). The relationship between school principals' instructional leadership behaviours and the organisaitonal health of schools, Educational Administration in Theory and Practice, 19(4), 629-664.

Rolff, H. G. (2008). Konzepte und Verfahren der Schulentwicklung. Fernstudium.

Roney, K., Coleman, H., \& Schlichting, K. A. (2007). Linking the organizational health of middle grades schools to student achievement. NASSP Bulletin, 91(4), 289-321. https://doi.org/10.1177/0192636507310161 
Şahin, A. E. (2000). Qualifications of elementary school principals. Educational Administration in Theory and Practice, 6(2), 243-260

Sarıkaya, N., \& Erdoğan, Ç. (2016). Relationship between the instructional leadership behaviors of high school principals and teachers' organizational commitment. Journal of Education and Practice, 7(3), 72-82.

Schumacker, R. E., \& Lomax, R. G. (1996). A beginner's guide to structural equation modeling. Hilsdale, NJ: Erlbaum.

Sergiovanni, T. J. (1984). Leadership and excellence in schooling. Educational leadership, 41(5), 4-13.

Serin, M. K., \& Buluç, B. (2012). The relationship between elementary school principals' instructional leadership behaviours and teachers' organizational commitment. Educational Administration in Theory and Practice, 3(3), 435-459.

Shannon, G. S., \& Bylsma, P. (2007). Nine characteristics of high-performing schools: A research-based resource for schools and districts to assist with improving student learning. Washington Office of Superintendent of Public Instruction. Accessed from http://files.eric.ed.gov/fulltext/ED499819.pdf on 26.1.2017

Şişman, M. (2011). Instructional leadership ( $3^{\text {rd }}$ Edition). Ankara: Pegem.

Şişman, M. (2011). Quest for the perfect in education. Ankara: Pegem

Şişman, M. (2016). Factors related to instructional leadership perception and effect of instructional leadership on organizational variables: A meta-analysis. Educational Sciences: Theory \& Practice, 16, 1761-1787. https://doi.org/10.12738/estp.2016.5.0172

Smith. F. W., \& Andrews, R. L. (1989). Instructional leadership: How principals make a difference. Virginia: Alexandria, Association for Supervision and Curriculum Development. Accessed from http://files.eric.ed.gov/fulltext/ED314826.pdf on 26.1.2017

Tsui, K. T., \& Cheng, Y. C. (1999). School organizational health and teacher commitment: A contingency study with multi-level analysis. Educational Research and Evaluation, 5(3), 249-268. https://doi.org/10.1076/edre.5.3.249.3883

Turan, S. \& Şişman, M. (2000). Standards for school administrators: Views on the knowledge base of educational administrators. Balıkesir University Journal of the Graduate School of Social Sciences, 3(4), 68-87.

Turan, S., Yıldırım, N. \& Aydoğdu, E. (2012). School principals' perspectives on their own duties. Pegem Journal of Education and Instruction, 2(3), 63-76.

Türker, Y. (2010). The relationship between the effectiveness levels of elementary schools and organizational health. Unpublished Master's thesis. Akdeniz University, Antalya.

Vassie, L. H., \& Lucas, W. R. (2001). An assessment of health and safety management within working groups in the UK manufacturing sector. Journal of Safety Research, 32(4), 479-490. https://doi.org/10.1016/S0022-4375(01)00064-0

Williams, D. (2009). Case for change: Building leadership capacity in urban high schools (Doctoral dissertation). Retrieved from ProQuest Dissertations and Thesis database. (UMI No. 3368671).

\section{Copyrights}

Copyright for this article is retained by the author(s), with first publication rights granted to the journal.

This is an open-access article distributed under the terms and conditions of the Creative Commons Attribution license which permits unrestricted use, distribution, and reproduction in any medium, provided the original work is properly cited. 